Relations industrielles

Industrial Relations

\title{
Public vs Private Sector Compensation
}

\section{Gilbert Levine}

Volume 35, numéro 1, 1980

URI : https://id.erudit.org/iderudit/029042ar

DOI : https://doi.org/10.7202/029042ar

Aller au sommaire du numéro

\section{Éditeur(s)}

Département des relations industrielles de l'Université Laval

ISSN

0034-379X (imprimé)

1703-8138 (numérique)

Découvrir la revue

Citer cet article

Levine, G. (1980). Public vs Private Sector Compensation. Relations industrielles / Industrial Relations, 35(1), 128-136. https://doi.org/10.7202/029042ar

Tous droits réservés (C Département des relations industrielles de l'Université Laval, 1980
Ce document est protégé par la loi sur le droit d'auteur. L’utilisation des services d'Érudit (y compris la reproduction) est assujettie à sa politique d'utilisation que vous pouvez consulter en ligne.

https://apropos.erudit.org/fr/usagers/politique-dutilisation/ 


\section{Public vs Private Sector Compensation}

\section{Gilbert Levine}

Now that the Anti Inflation Board wage controls are being phased out, the Government of Canada is putting forward a new form of wage controls for public employees.

This time it's called ACTC. That stands for Average Comparability of Total Compensation - a term which we will hear with increasing frequency in the months and years to come.

It was first proposed on March 8, 1978 by the Government in the form of Bill C-28, "An Act to Amend the Public Service Staff Relations Act". If enacted, no doubt the federal government will put strong pressure on crown corporations, provincial and municipal governments to follow the lead.

ACTC is a formula devised by federal technicians which is purported to measure the total cost of both wages and fringe benefits of public employees. The total compensation of comparable jobs with a representative sample of private sector employees will similarly be measured as a means of ensuring that pay rates in the Public Sector never exceed rates in the private sector.

The proposed scheme calls for costing thirteen wage and fringe benefit elements and comparing them, occupation by occupation, with those in the private sector.

The thirteen elements to be compared include:

1. Wages and salaries

2. Pensions (including indexing provisions \& supplementary retirement benefits)

3. Life insurance

4. Disability insurance

5. Severance pay

6. Supplementary health insurance

7. Employer's share of provincial health insurance

8. Sick leave/sickness indemnity plans

9. Paid holidays

10. Vacation leave

11. Scheduled hours of work

12. Paid rest periods

13. Overtime

* LEVINE, Gilbert, Research Director, Canadian Union of Public Employees. 
Under this proposal, the total average compensation of private sector workers would be established using the techniques developed by the A.I.B. Comparable public sector employees would then be given the total amount of compensation, i.e. the new "guidelines", for which they would be allowed to bargain.

Accordingly, negotiations would be limited to bargaining for the appropriate mix of total compensation, i.e., wages relative to fringe benefits. In other words, unions would only be able to bargain on how the pie is to be cut. There would be no bargaining on the size of the pie.

Another feature of the scheme would include specific guidelines whereby arbitrators in interest disputes would be required to follow the ACTC formula in their awards.

Bill C-28 is falsely trying to accuse public employees for the economic mess we are in today. If that lie succeeds, it will take the heat off the corporations and their governments, who are the real creators of unemployment and inflation.

This new gimmick is all part of a continuing propoganda lie that public employee wage increases in recent years have sparked inflation in Canada. But the facts have consistently shown that pay increases for public employees have never lead, but always followed, increases in industry:

Percentage wage increases in public sector wage settlements were less than private sector settlements in every year between 1968 and 1974. It was only in 1975, when public sector unions began to "catch up" to industrial workers, that the Government imposed wage controls.

In the eight years prior to the introduction of wage controls the average annual percentage increase in base rates in new settlements in the private sector totalled 81.0 percent. For the public sector it was 81.5 percent. Therefore, the annual average differential between public and private sector wage settlements was less than one-tenth of one percent.

In comparing wage settlements between the public and private sectors since the start of collective bargaining in the federal public service in 1968 until the third quarter of 1976, the Honorable John Munro, Minister of Labour recently stated:

"The federal public service is trailing marginally behind the major bargaining units of the private sector. The public service, including all levels of government, is only marginally ahead of the major bargaining units of the private sector. Some of the increases in the provincial and municipal wage levels in this period can be accounted for by the fact that public employees obtained bargaining rights relatively recently and were using their bargaining power to catch up to private industry wage levels." 1

1 From an address to the National Convention of the Canadian Merchant Service Guild, Vancouver, March 8, 1978. 
In spite of this ACTC brings forth the concept that profit making private industry must be the "leader" in wages and benefits. Employees who provide public services must then follow.

This is a wrong concept on two grounds:

1. Rates of pay should not only be set on the basis of skill, responsibility, effort, education, working conditions, etc., but also on the basis of the social value of the job in the community. For example, a floor sweeper who provides a useful community service in a hospital should be paid more than a floor sweeper in a chewing gum factory. That's not the case now. Rates of pay of public employees, who perform work that in many cases is so essential that they are forbidden by law to strike, should not have to follow rates of pay for non-essential workers.

2. Instead of always following the private sector, public employers should be free to be MODEL employers, to be followed by the rest of the community. Governments as employers should be free to introduce new concepts of industrial relations and new ideas on working conditions and benefits, as they have done in the past. Many years ago governments provided their employees with paid vacations, paid sick leave and pensions, long before they were known in private industry. If we had waited for private industry to introduce these concepts, they may still be unknown today in Canada.

What are some of the dangers of ACTC for public employee unions?

\section{EVERYTHING IS NOT BEING COMPARED}

The factors to be compared between public employees and private employers have been restricted by the federal government formula. When the Honorable Robert Andras, President of the Federal Treasury Board met with officers of the Canadian Labour Congress in February to discuss the ACTC formula, he was asked if the Government also intended to match non monetary benefits of public employees with benefits which apply in industry. The CLC officers had in mind the right to strike, the right to negotiate on pensions, on promotions, on job classifications etc. Andras replied that the Government would decide on the elements to be compared and there was no intention to match these matters with industrial employees.

\section{NO GUARANTEE OF OBJECTIVE STATISTICS UNDER ACTC}

Unions and Governments will not likely be able to agree on which private employers would be included in a representative sample for comparison purposes. Nor will there be much agreement on job matches. But under ACTC Governments, as employers, will assume the responsibility of collecting "the facts" on average wage comparability. Where there will be a disagreement between the government and a union on any aspect of the sample, a government agency will make the decision. Governments, or their 
agencies like the Pay Research Bureau, will select the companies to be surveyed, will select the job matches between the public and private employers and will also make all the calculations. This is on a par with one team (The Government) in a hockey match being allowed to make and amend the rules (The Public Service Staff Relations Act), to select the facts (Pay Research Bureau), to appoint the referee (the Arbitrator) in its game against the other team (the Unions).

How will a Union bargaining with the Government as an employer be able to determine the value of total compensation of the bargaining unit? It is obvious that it would be impossible for the Union to obtain accurate information when the Government has all the records. It is also obvious that the Union would have to accept whatever the Government says the group would be entitled to. Surely, this is not a fair approach to bargaining.

Anyone who has negotiated with public employers in recent years will know how governments, as employers, have distorted survey "facts" to their own benefit in bargaining.

The people with the most "know how" in costing wages and benefits in Canada are the technicians of the A.I.B. These "experts" in rolling back the hard won gains of workers will now be recruited as the impartial compensation surveyors of the new ACTC. Is it any wonder that trade unionists will be suspicious of the whole scheme?

\section{COMPLICATIONS IN COMPARABILITY}

Even if the principle of wage comparisons based on total compensation was correct, the complications of gathering accurate compensation information are immense. Part of the difficulty stems from the fact that most employers do not keep accurate compensation records. Many items of compensation in the private sector, such as subsidized meals, Christmas and other bonuses, discounts, mortgage loans, stock options etc. are difficult to measure. It is erroneous to assume that all elements of compensation are measurable in accounting terms.

The United State Public Service Commission has been examing the total compensation approach for some time. That body recently stated that it still needed several more years of experimenting before it might be considered valid. Could Canada's speed in entering the scheme be a case of "fools rush in where angels fear to tread?"

\section{COSTING PROBLEMS UNDER ACTC}

Agreement between unions and government employers on "costing" of wages and benefits under ACTC will be difficult, or impossible. For example, assuming that a government matches a $6 \%$ employee contribution to a pension plan, it would mark that down as a $6 \%$ payroll expenditure. But most governments use this pension money to invest in their own operations. In effect, they "lend" themselves money at greatly reduced rates of interest. 
This would have the effect of reducing the real pension cost by approximately one-half. As such, the $6 \%$ payroll pension "cost" charged as compensation against the union may only cost the employer 3\% in real terms.

One of the thirteen "costed" items under ACTC is overtime. Where a union negotiates an improvement in overtime premiums from the standard time and one half to double time, it would be charged for the "cost" of this improvement. However, if this increased penalty against the ernployer causes him to hire additional employees at straight time rates and eliminate all overtime premiums, will this be considered as a reduced cost to the employer? Not under ACTC. Similarly, if the introduction of a rest period "costed" at 3\% of payroll results in an increase in productivity of 5\%, ACTC would still consider this as a new cost at $3 \%$, when, in actual fact, costs have been reduced.

\section{ACTC WILL BE BASED ON DATED MATERIAL}

In the past, the government as a bargainer has relied on wage and benefit surveys of the previous year to determine wage rates for public employees for the following year. This will continue under ACTC. Public employer offers will always be based on wage material that is several years out of date. Therefore, with private sector unions demanding large wage increases to meet inflation, public employee unions under ACTC will always lag behind.

\section{CORPORATIONS HAVE A STAKE IN ACTC}

As a means of covering up its own bad image, the corporate sector in recent years has been campaigning strongly against the conditions of employment in the public sector. If the corporate sector is successful in keeping down public sector wages and benefits, there will be less demand to improve the pay and benefits of its own employees. (Indeed, this may well be the rationale of pressure on government by corporations to bring in ACTC.) If industrial employers know that the statistics they supply on wage comparability will be used to set wages and benefits for public employees, there will be a strong pressure on them to feed biased information into a survey. They will tend to highlight poor wages and conditions and this would seriously affect the validity of any comparisons.

\section{UNDER ACTC MANY MATTERS ARE NOT NEGOTIABLE}

Once the total compensation is determined through ACTC, will a public employee union be free to determine how the compensation is divided between wages and benefits? Not exactly. Many of the public sector benefits are determined by legislation which is not subject to collective bargaining. For example, where the law says the employer shall pay $6 \%$ of an employee's wages into a pension, the union will not be able to say in bargaining that it would prefer to forgo the $6 \%$ and take 3 extra weeks vacation with pay. 
Even in matters not covered by legislation, there may well be many rigidities built into the system of ACTC. One doubts whether the Government would allow every bargaining unit to choose its own mix of total compensation. Would it allow one bargaining unit to give up two 15 minute rest periods and cut the working day by half an hour? Or another group to eliminate rest periods in exchange for three extra weeks vacation? If that's what bargaining on total compensation really means, it could really end up in a wide variety of compensation packages.

\title{
NO IMMEDIATE CATCH UP UNDER ACTC
}

If the ACTC formula shows that the compensation of a particular classification in the public sector is substantially behind a comparable private sector position, will Bill C-28 provide for an immediate catch up? Not necessarily. The proposed amendment to the PSSR Act states:

\begin{abstract}
"If the existing aggregate of compensation is substantially less than that for similar or analogous occupations or work, any arbitral award rendered shall provide for the gradual elimination of the differences, taking into account the relative magnitude of the difference and the prevalent rate of increase in aggregate of compensation outside the public service."
\end{abstract}

\section{ACTC WILL MAKE BARGAINING RIGID}

The total compensation formula is similar to the A.I.B. arithmetic guidelines which are also based on an aggragate of pay, benefits, and other conditions of employment. With limits placed on compensation during the A.I.B., some unionists thought they would be able to concentrate their bargaining on non-wage working conditions and make some important breakthroughts. In fact, the opposite proved true. The imposition of total compensation under the A.I.B. removed the flexibility from collective bargaining. The A.I.B. has demonstrated that minimal, if any, progress can be made in improving working conditions when the compensation is frozen into one package. Similarly ACTC will not only freeze compensation bargaining, but it will also freeze bargaining on key non wage issues, such as job security, safety, promotions, etc.

\section{ACTC WILL LEAD TO COMPUTERIZED BARGAINING}

ACTC will lead to what may be called "computerized collective bargaining". Wage and fringe benefit facts will be placed in a computer, which will then spit out "the facts" on what changes may be allowed in a collective agreement. Gone will be the role of the active rank and file member and steward. Unions will cease to exist as effective organizations. Bargaining in the public sector will become highly bureaucratic exercise. It will be the preserve of the technocrats, with little meaning to the membership. 
Once the ACTC system is operational, governments will likely bring pressure to bear to decertify public employee unions. The argument will go: "Now that we have a "fair" system of comparisons and the computer is working well, you do no need a union any more.

\section{ACTC WILL LOWER THE STANDARDS FOR PUBLIC EMPLOYEES}

In the past, the federal government has stated that it should compare its conditions of employment with those in effect with good employers. This normally meant comparisons which did not include small employers with poor working conditions. Now under ACTC, the government wants comparisons to be made with all employers, large and small, unionized and nonunionized, and with good and bad conditions. This new concept of an "average" will certainly have the effect of lowering the standard of public employees.

In accordance with the Public Service Staff Relations Act, guidelines to arbitrators in the past have been flexible and were on the basis of the "need to establish terms and conditions of employment that are fair and reasonable in relation to the qualifications required, the work performed, the responsibility assumed and the nature of the services rendered"'.

Under section 68 of the PSSR Act, an interest dispute arbitrator or negotiator could set wage rates based "on the needs of the public service for qualified employees". It appears that the Government no longer considers this need important. With Bill C-28, this section of the Act would be deleted and be replaced by the simple comparability formula. This would completely tie the hands of government recruitment officers who would no longer be able to improve salaries to attract qualified employees who are in short supply. Another example of this Government putting the needs of the private sector first!

\section{ACTC WILL WEAKEN UNIONS}

Labour unions are not merely economic organizations to bargain for wages and fringe benefits. Unions also serve to defend workers' rights on the job, such as grievances, promotions, discipline, occupational health and safety etc. Unions are also organizations to bring about social and political change. Denials of free collective bargaining on economic issues, will weaken the effectiveness of labour unions on all other matters as well. ACTC will weaken a union's ability to fight for justice on and off the job.

\section{ACTC IS DISCRIMINATORY AGAINST WOMEN PUBLIC EMPLOYEES}

The recent passage by the Federal Government of the Canadian Human Rights Act has been hailed as a progressive move. Section II of the Act provides for the principle of equal pay for work of equal value. However, Bill C-28 is directly opposed to the principle of equal pay for 
work of equal value. As such, this legislation discriminates against public service women and adds a new level of wage controls on them.

The Trudeau Government is taking away with one hand (Bill C-28), what it gave with the other (Human Rights Act). In order to have any meaning whatsoever, the comparison of equal pay for work of equal value must be made within the same company or place of work. Yet Bill C-28 establishes a principle of comparing occupations between companies, i.e., between unionized government employees and non-unionized private sector employees. Instead of comparing the worth of a public service female clerical worker with the worth of a higher paid male public servant, the Government now proposes to compare her with the clericals employed in banks, insurance companies and retail trade, where unionization is virtually nil. Thus, women in clerical and secretarial jobs in the unionized public sector will have a new wage ceiling. That wage ceiling will be the average pay of clerical jobs in private industry, where most women are unorganized.

In other words, public sector women will have their wage rates tied to the job ghetto rates of low paid jobs in private industry, where employers profit by discriminating against women.

This is directly contrary to the principle of comparison within the establishment, as defined in the equal pay section of the Canadian Human Rights Act.

\section{ACTC WILL PIT WORKER AGAINST WORKER}

By telling industrial workers that public employees are the cause of inflation and other economic problems, Governments are, in effect, seeking the support of industrial unions to keep down the wages and benefits of public employees. Therefore, ACTC is designed to pit the private employee against the public employee. In a labour movement divided between public and private employees, both will lose. No group of workers gains by holding down the wages of another group.

\section{ACTC MAY LEAD TO REGIONAL OR ZONAL RATES}

Section 68 of Bill C-28 directs arbitrators, and presumably government negotiators, to take "fair and reasonable account of... relevant geographical... and other elements of the aggragate of compensation". This appears like the thin edge of the wedge towards regional and zonal rates of pay. This in turn could lead to the break-up of national bargaining units and the further widening of income disparities between the various regions of Canada.

\section{COMPARING POOR WITH POOR WILL NOT BRING JUSTICE}

Unions should reject comparing the poor wages of one group of workers against the poor wages of another group of workers with the con- 
clusion that justice prevails because both groups are equally poorly paid. If the Government is so keen on comparisons, maybe comparisons should be made with those elements in society that do not work. This would include investors, coupon clippers, land speculators and other socially useless persons who produce nothing but who receive the highest per capita income.

For all of the above reasons, and many more, public employee unions will reject Average Comparability of Total Compensation as a new wrinkle in the Government's attempt to control public employee wages.

Unions will continue to look upon this new technique as a management negotiating tool to inflate and distort the real cost of a union's bargaining proposal.

Effective unions will bargain for wages and benefits, instead of bargaining on the basis of total compensation. They will bargain for collective agreement provisions and benefits on their merits and on the needs of their members, regardless of some distorted management cost estimates.

\section{Une étude sur une forme}

de pollution de plus en plus menaçante

LE BRUIT INDUSTRIEL

Ses méfaits et son contrôle

\section{par Guy LESCOUFLAIR}

En un texte qu'il a voulu rendre accessible au plus grand nombre, Guy Lescouflair, chef audiologiste au Centre hospitalier de l'université Laval, propose d'intéressantes solutions au problème du bruit industriel. Tout en soulignant la nécessité d'une planification d'ensemble de plusieurs champs de la connaissance humaine, il montre comment le contrôle du bruit est une chose relativement aisée et rentable sur les plans financier, ergonomique et social.

216 pages, 80 figures, 21 tableaux, $\$ 14$.

LES PRESSES DE L'UNIVERSITE LAVAL C.P. 2447, Québec G1K 7R4 